\title{
Design potent antimicrobial peptides against the ESKAPE pathogens based on human cathelicidin LL-37
}

Guangshun Wang, Ph.D.

Department of Pathology and Microbiology

$4^{\text {th }}$ International 


\section{Outline}

I. Why bother with peptides?

II. How to identify peptide leads?

III. What's the state of the art of

human LL-37 engineering?

IV. Summary 


\section{Part I: Why peptides?}

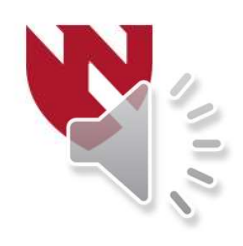




\section{Why bother peptides?}

Small molecules: not specific enough;

Large biologics: limited oral bioavailability.

Consequently, there is a great interest in developing peptide drugs. 


\section{Peptide drug market}

Lupron (Abbot lab) for prostate cancer sold over 2.3 billion in 2011.

Over 60 FDA-approved peptide drugs (e.g., daptomycin, colistin);

140 under clinical trials;

500 under preclinical development.

Drug Discovery Today 2015; 20:122-128. 


\section{Goals of peptide drug development}

To identify proper leads and overcome the hurdles toward practical applications. 


\section{Drug development stages}

Lead identification (Novel?)

Optimization in vitro (SAR)

$\downarrow$

In vivo efficacy test (PK and PD);

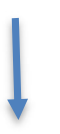

Clinical trials (Safe, effective, afforadable?)

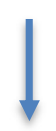

Therapeutic use/withdrawal from the market 


\section{Methods for lead identification}

(1)Library screening

in the lab;

in the field;

and in silico;

(2) Structure-based design

(Rational design). 


\section{Select antimicrobial peptides (AMPs) in practical use (red) and under development (blue)}

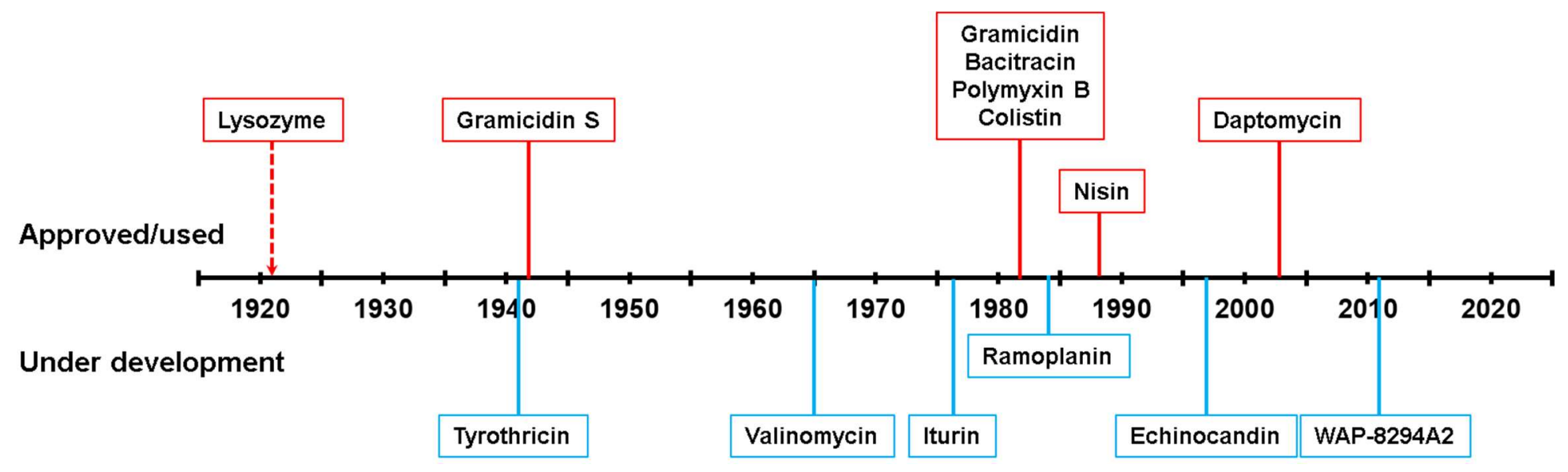

Note that lysozyme is regarded as the first AMP and the beginning of innate immunity.

Mishra, B., Reiling, S., Zarena, D., Wang, G. (2017). Host defense antimicrobial peptide as antibiotics: design and application strategies. Curr. Opin. Chem. Biol. 38, 87-96. 


\section{Natural Occurring Antimicrobial Peptides}

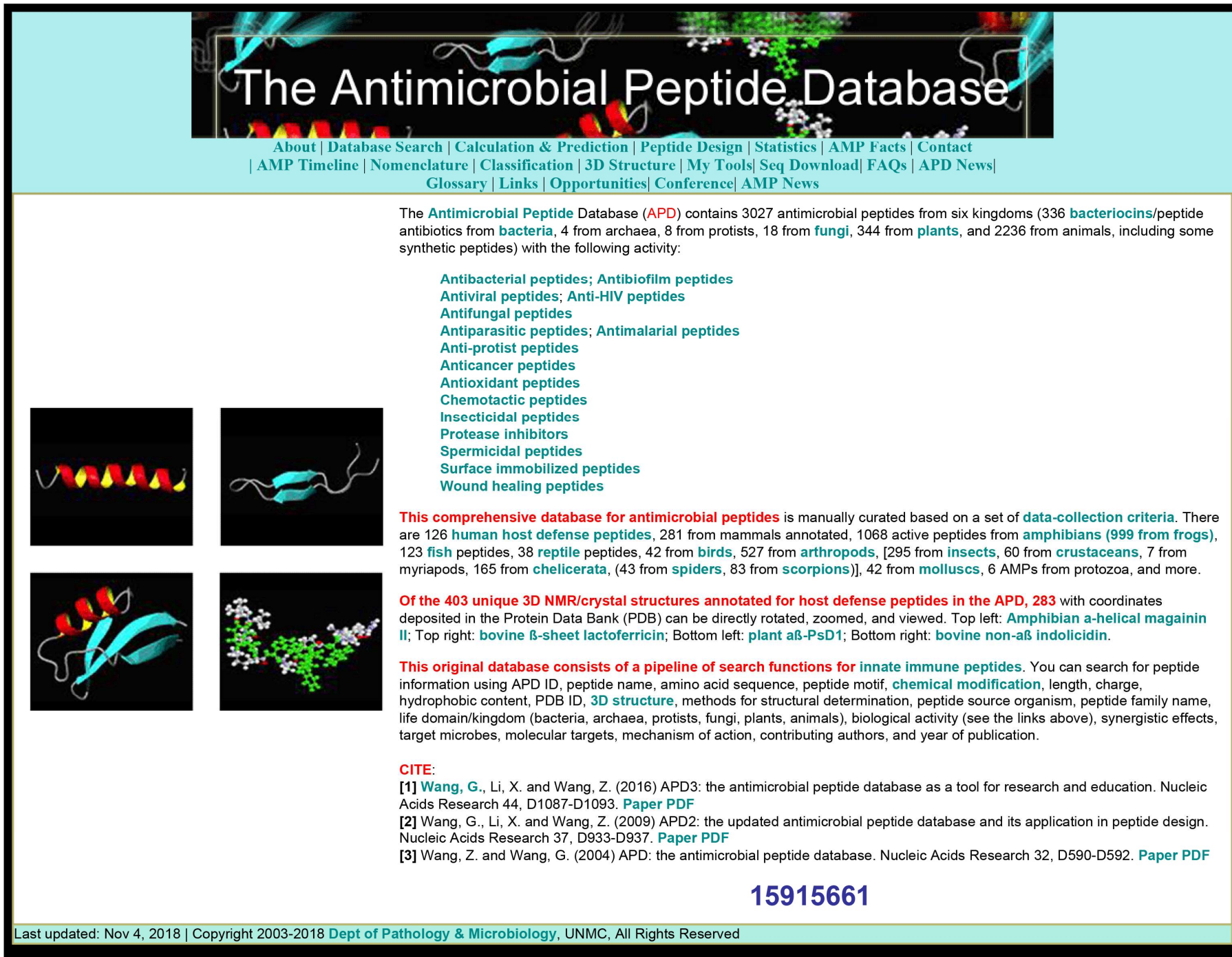

http://aps.unmc.edu/AP (Nov2018) 


\section{AMPs from the six kingdoms}

\begin{tabular}{|l|l|} 
Kingdom & Count \\
\hline bacteria & 336 \\
\hline Archaea & 4 \\
\hline Protists & 8 \\
\hline Fungi & 18 \\
\hline Plants & 344 \\
\hline Animals & 2236 \\
\hline
\end{tabular}

Archaea,Protists,

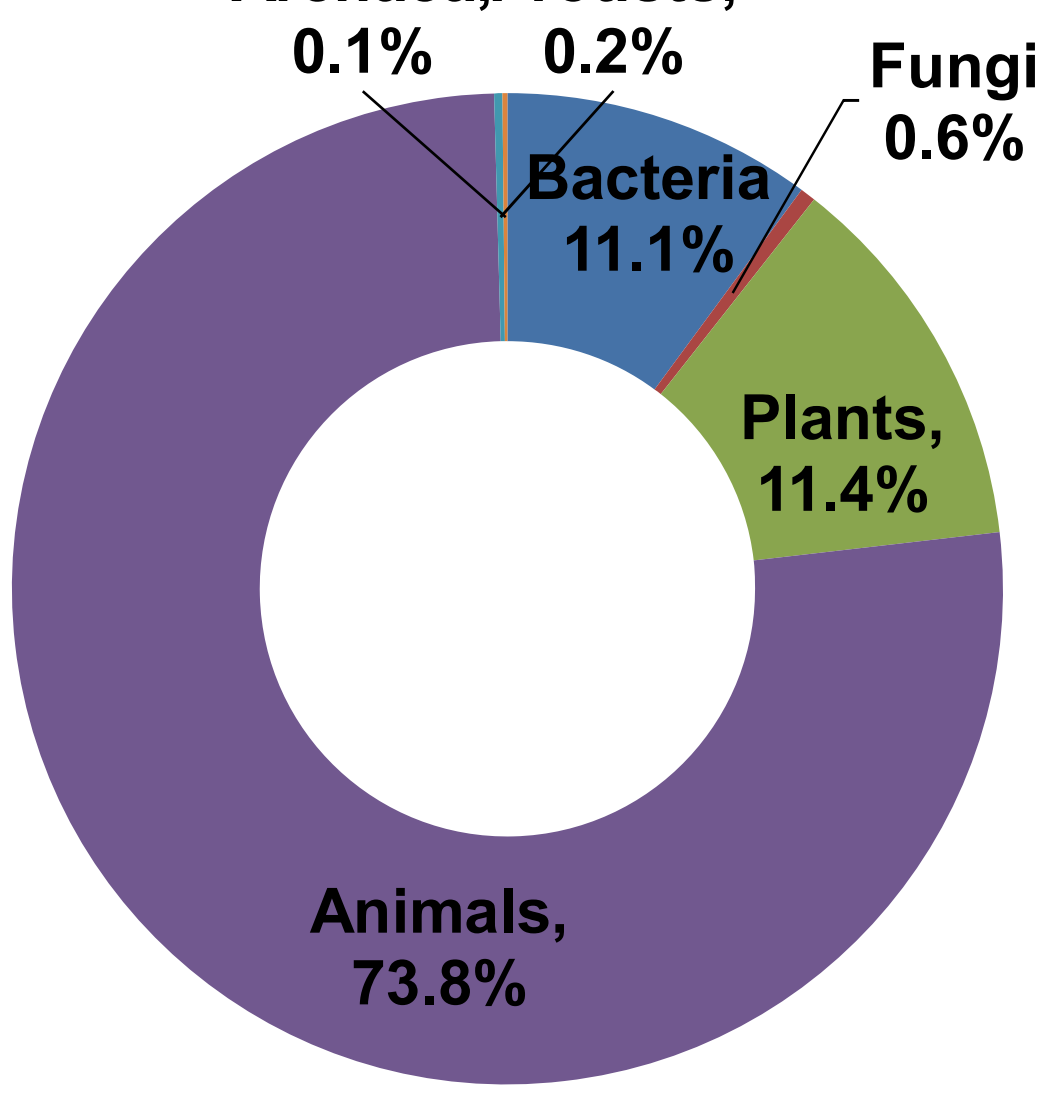

Eukaryota: 2606 (86\%)

Total: 3027 (Oct 2018) 


\section{Unified classification of 3D structures: $\alpha, \beta, \alpha \beta$, and non- $\alpha \beta$}

A. Frog aurein 1.2

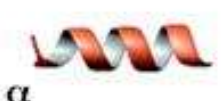

B. Human cathelicidin LL-37

C. Frog distinctin

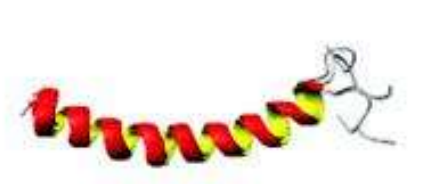

$\alpha$

F. Rhesus theta defensin 1 (RTD-1)

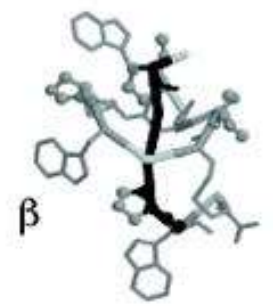

I. Fungal plectasin

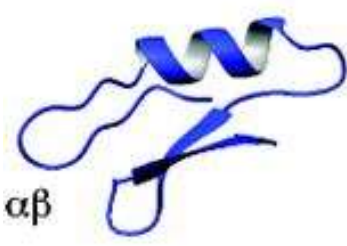

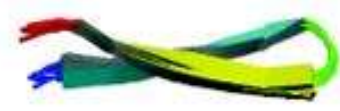

$\beta$

J. Mussel MGD-1

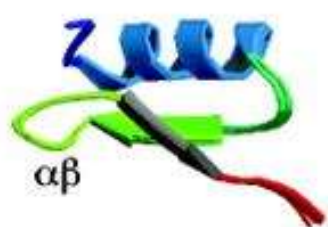

\section{reccere} (ब)

$\alpha 60000$

G. Plant kalata B1

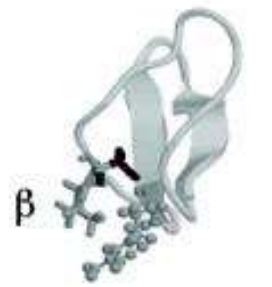

K. Human beta defensin 1 (hBD-1)

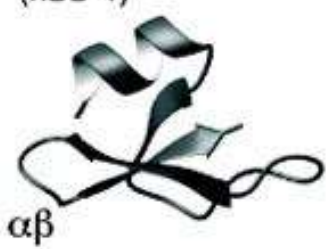

D. Worm caenopore 5

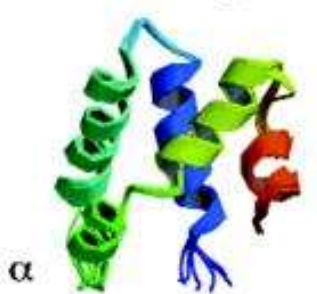

H. Human alpha defensin 1 (HNP1)

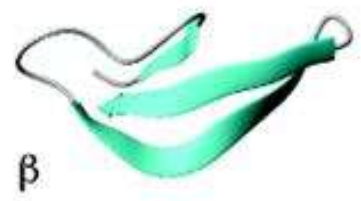

L. Bovine indolicidin

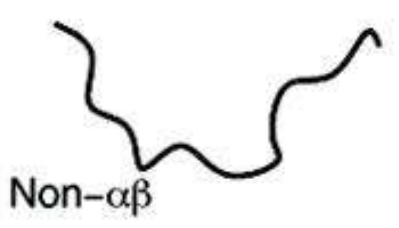

Wang, G. (ed.) 2010. Antimicrobial Peptides: Discovery, Design and Novel Therapeutic Strategies, CABI, England. 


\section{Select human AMPs}

Lysozyme (1922) in saliva, tears, and intestine; Alpha-defensins HNP-1 (1985) in neutrophils and bone marrow; Histatins (1988) in saliva;

RNase 2 (1990) in eosinophils;

Beta-defensin HBD-1 (1995) in kidney, skin, saliva; Cathelicidin LL-37 (1995) skin and neutrophils; Granulysin (1998) in cytolytic T cells and NK cells; Ubiquicidin (1999) in macrophages;

Thrombocidin-1 (2000) in human blood platelets; Dermcidin (2001) in skin and sweat

Wang G (2014) Pharmaceuticals 7, 545-594. 


\section{Cathelicidins: biosynthesis and cleavage}

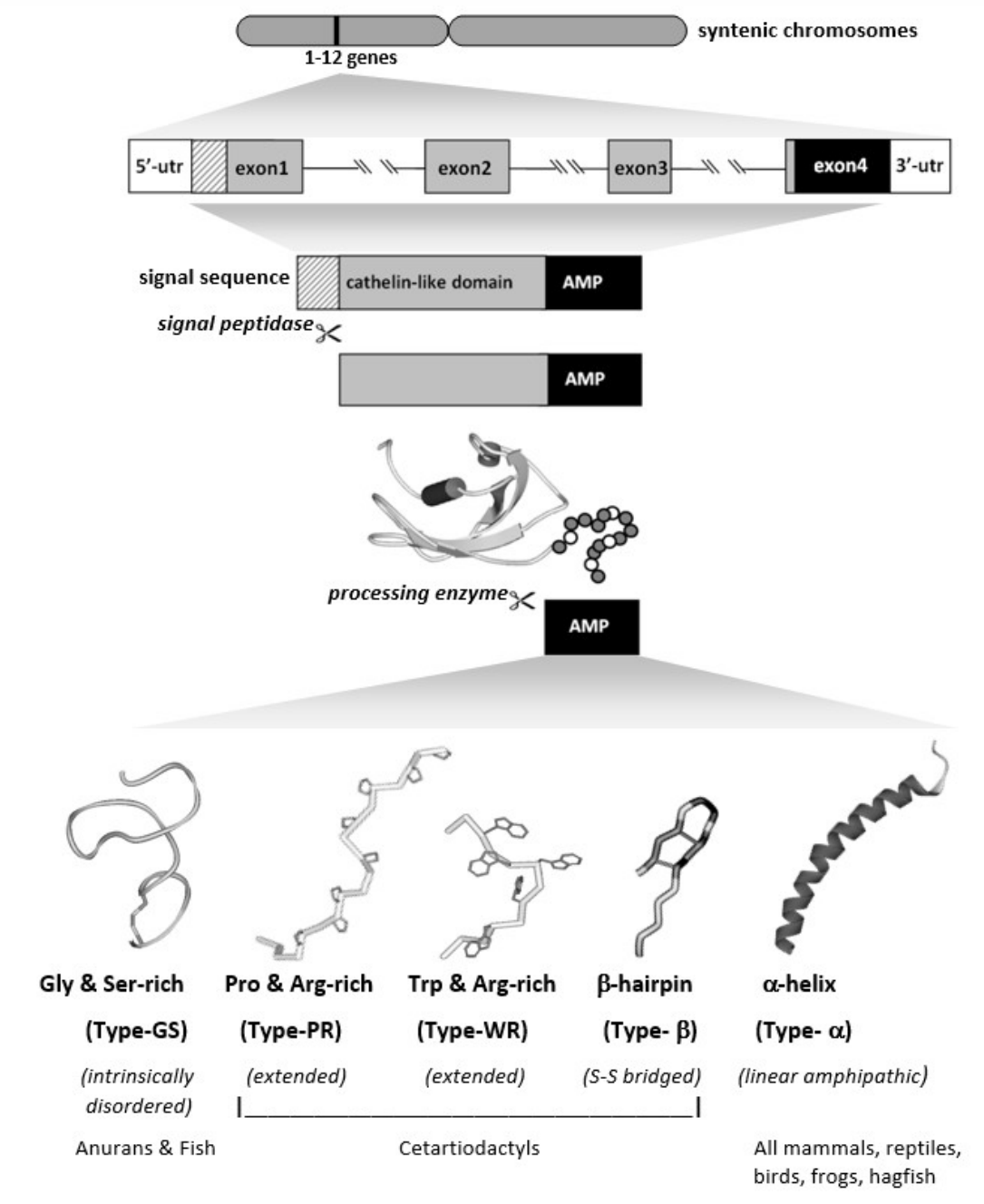

N-terminus:

The cathelin domain

is highly conserved and can be used to predict cathelicidins in the genome.

C-terminus:

The mature antimicrobial peptide is extremely variable in terms of sequence and structure.

Tossi et al. (2017). In "Antimicrobial Peptides" (Wang G, ed.), Chapter 2 


\section{The only human cathelicidin: a helical peptide}

The human genome project was started in 1990 and completed 2003.

There are multiple copies of genes in horse, sheep and cattle, but only one cathelicidin gene in humans. 


\section{Cathelicidin: one gene, multiple peptides}

The Cathelin domain Mature AMP

Year

1995

1996

个

Predicted FALL-39

2003

2016

个

Isolated LL-37

个

Isolated ALL-38

Refs: 1) Agerberth et al., 1995; 2) Gudmundsson GH et al., 1996; 3) Sorensen OE et al, 2003 ; 4) Murakami et al., 2016 (lesion vesicle of palmoplantar pustulosis in the skin). 


\section{Human cathelicidin LL-37 and its relationship with disease}

Patients with morbus Kostmann and atopic dermatitis have a low level of cathelicidin (Putsep et al., 2002).

Gene KO mice increased infection and overexpression reduced infection (Nizet et al., 2001; Lee et al. 2005).
Binding to LPS (endotoxin) protects rats from sepsis (Cirioni et al., 2006). LL-37 is reduced in cystic fibrosis due to interactions with DNA and filamentous Factin (Bucki et al. 2007).

LL-37 is overexpressed in breast, ovarian and lung cancers (Wu, Wang, Coffelt et al. 2010). 


\section{Multiple functions of LL-37: an innate immune peptide}

\section{Antimicrobial}

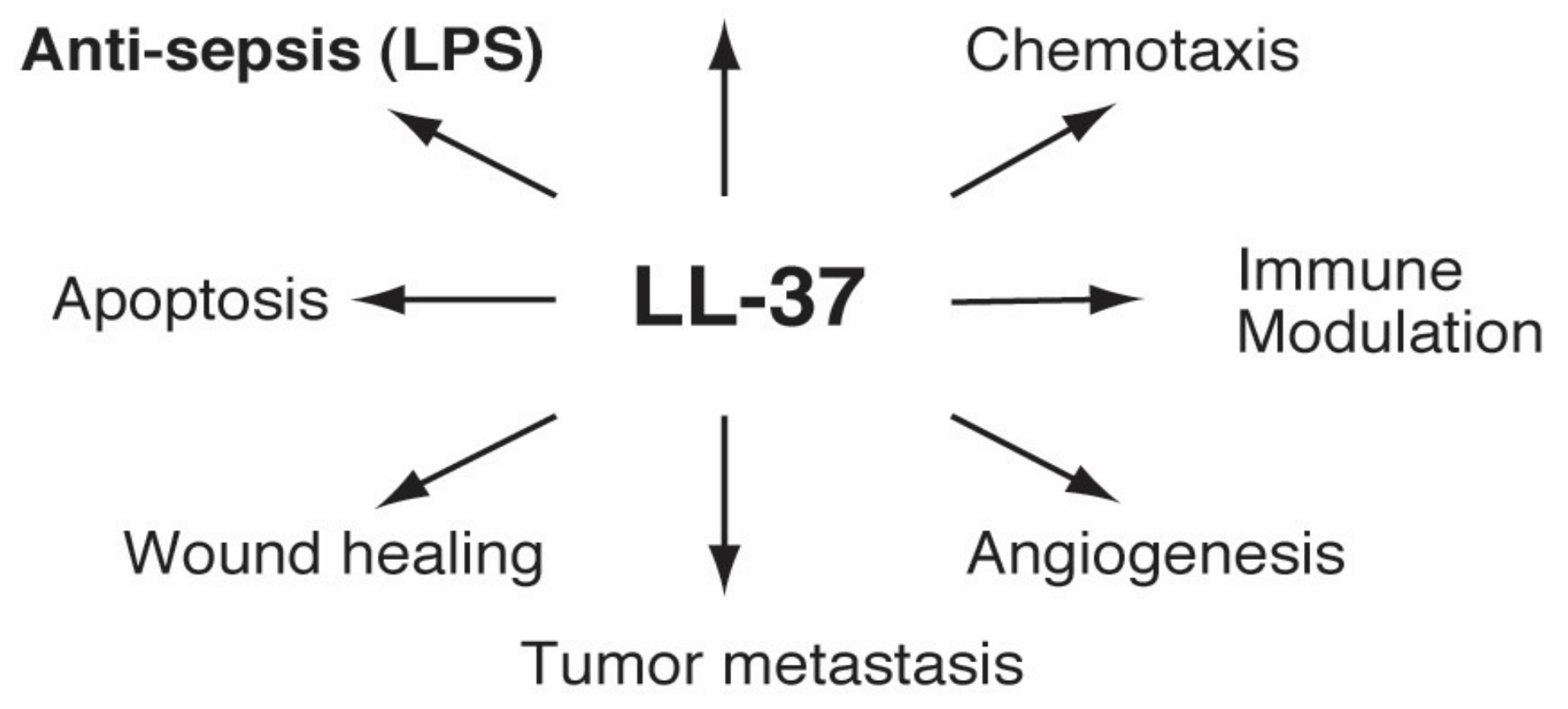

Wang et al. (2014) Biochim. Biophys. Acta 1838: 2160-2172. 
There is a great interest in developing $L L-37$ into therapeutic molecules 


\section{Part II: How to identify peptide leads?}

Antimicrobial peptides (AMPs) 


\section{LL-37-based peptide library}




\section{Peptide library design}

Commonly designed libraries:

1) Overlapping library (seq scanning);

2) Alanine scanning;

3) Positional library;

4) Truncation;

5) Random library;

6) Scrambled library (seq is important). 


\section{LL-37 peptides}

1. 37 amino acids (long and costly);

2. Decide on the peptide length $(20,22$, 24mer?);

3. Scan the sequence from the $\mathrm{N}$-terminus to the C-terminus;

4. Make peptides;

5. Quality check;

6. Antimicrobial assays

7. Cytotoxicity assays

8. Most selective and potent peptide. 


\section{LPS-neutralizing activity}

Peptide Sequence

IC50 (UM)

LL-37 LLGDFFRKSKEKIGKEFKRIVQRIKDFLRNLVPRTES 0.29

LL-22 LLGDFFRKSKEKIGKEFKRIVQ $>3$

IG-24(P60)

IGKEFKRIVQRIKDFLRNLVPRTE $\quad 0.48$

P60.4 IGKEFKRIVERIKRFLRELVRPLR 0.55

The most promising peptide is $\mathrm{P} 60.4$, a 24 amino acid peptide with similar efficacy as LL-37 in terms of LPS and LTA neutralization and lower pro-inflammatory activity.

Nell MJ et al. (2006) Peptides. 2006 Apr;27(4):649-60. 


\section{SAAP-148 is topically effective}

\section{Peptide Sequence}

LL-37 L L GD F FR K SKEKIGKEFKRIVQR IKDFLR NLVPRTES P139 LKKLWKR V F I WKR IFR Y LKRPVR P140 LRRLWKRLVRIIKRIYRQLKRPVR P141LRRLYKRVFRLLKRWWRYLKRPVR P142 LRR LWKRLVKILKRWFRYLRRPVR P143 LRRLYKRVVKLWKRLFRQLRRPVR P144 LKKLYKR VAKIWKR W IR Y LKKPVR P145 (SAAP-145) L KR L Y K R L A K L I KR L Y R Y L KK P V R P146 LKKLYKRLFKILKRILR YLRKPVR P147 L K K L W K R L A R L LKR F IR Q LRR P V R P148 (SAAP-148) LKR VWKR VF L LKR Y WR Q LKKPVR

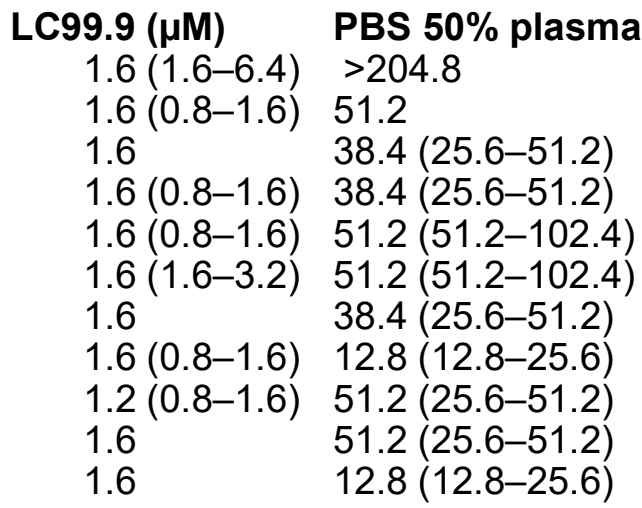

1. SAAP-148 formulated in an ointment is safe in an animal model (a $3.75 \%$ (w/w) hypromellose gel base); 2. SAAP-148 ointments are highly effective against (biofilm)-associated skin infections.

de Breij A et al. (2018). Sci Trans/ Med. Jan 10;10(423). pii: eaan4044. 


\section{Structure-based design}




\section{Physical basis of peptide selectivity}

a

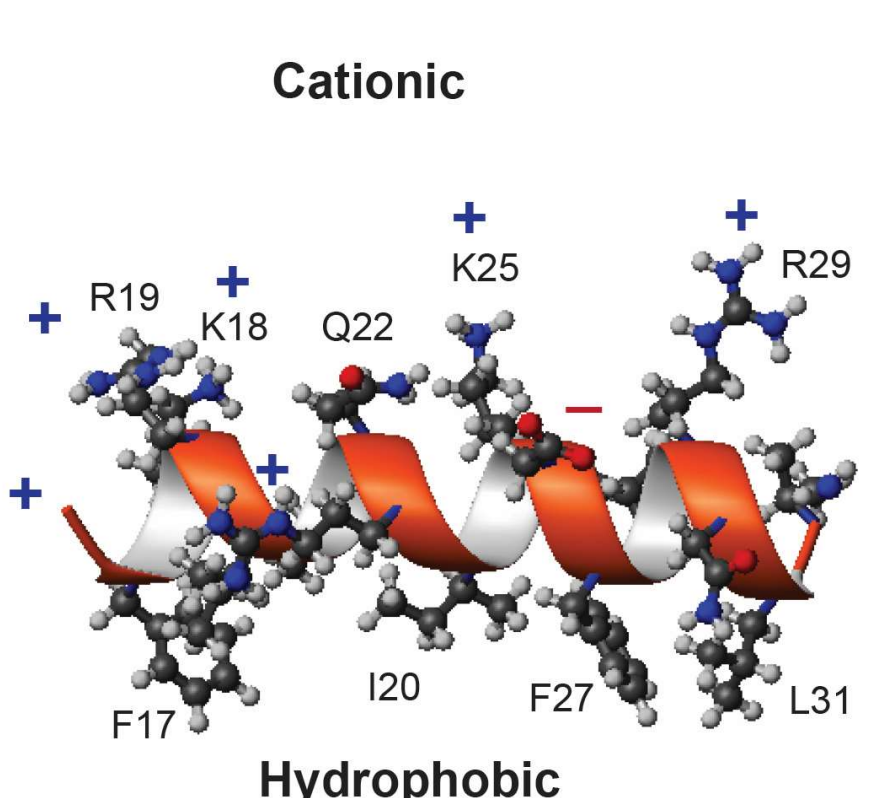

b

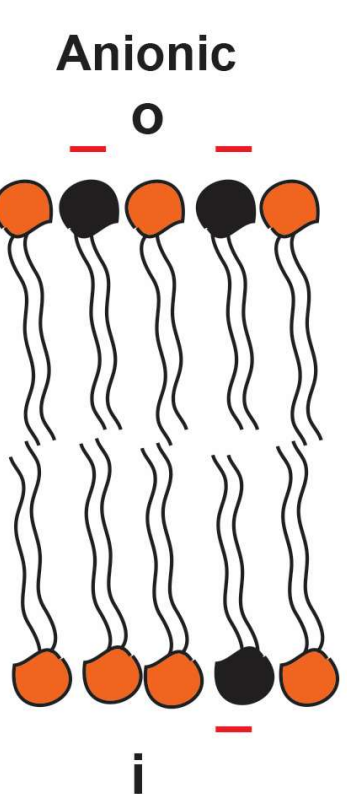

C Neutral

0

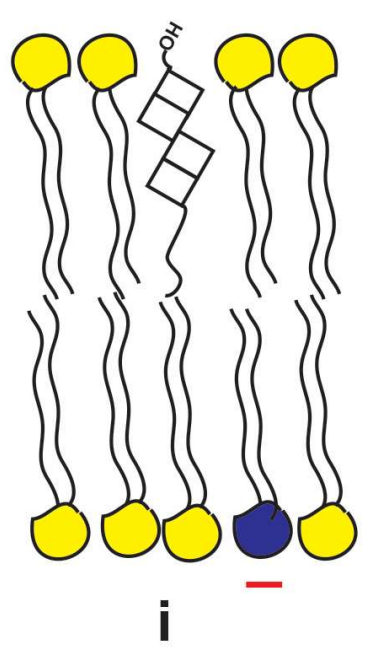

The amphipathic helix of cationic AMPs (a) is ideal to interact with anionic bacterial membranes (b), but not zwitterionic human cell membranes (c).

Mishra, B., Reiling, S., Zarena, D., Wang, G. (2017). Host defense antimicrobial peptide as antibiotics: design and application strategies. Curr. Opin. Chem. Biol. $38,87-96$. 


\section{Membrane-mimetic Models}

Lipid Bilayers

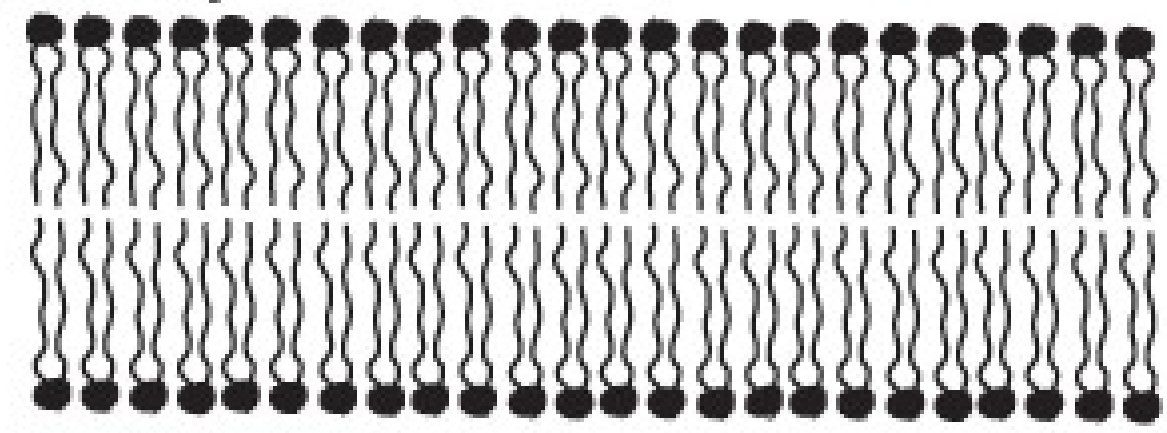

Bicelles

Micelles
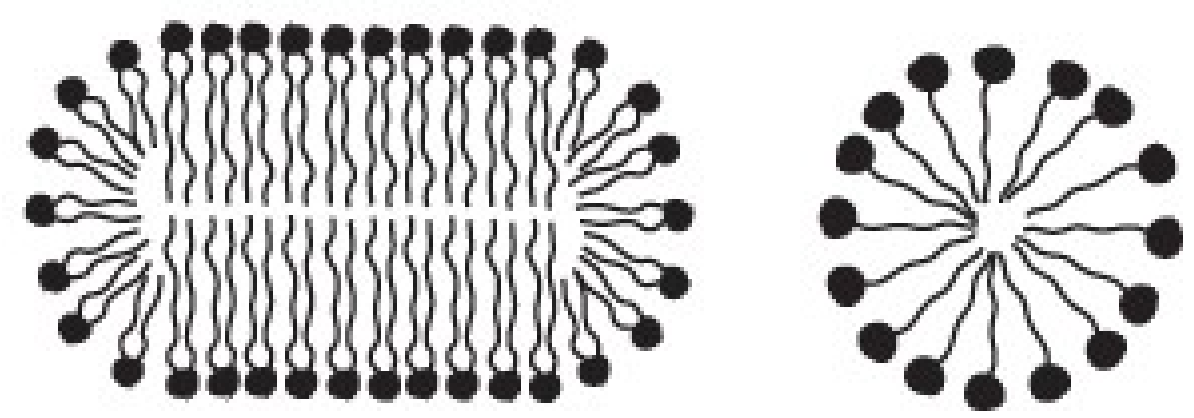

The smaller the particles, the high resolution the solution NMR spectra.

Wang G. (2010). In “Antimicrobial Peptides" (Wang G, ed.), Chapter 9. 


\section{Identification of the Core Antibacterial and Anticancer Region in Human LL-37 by NMR}
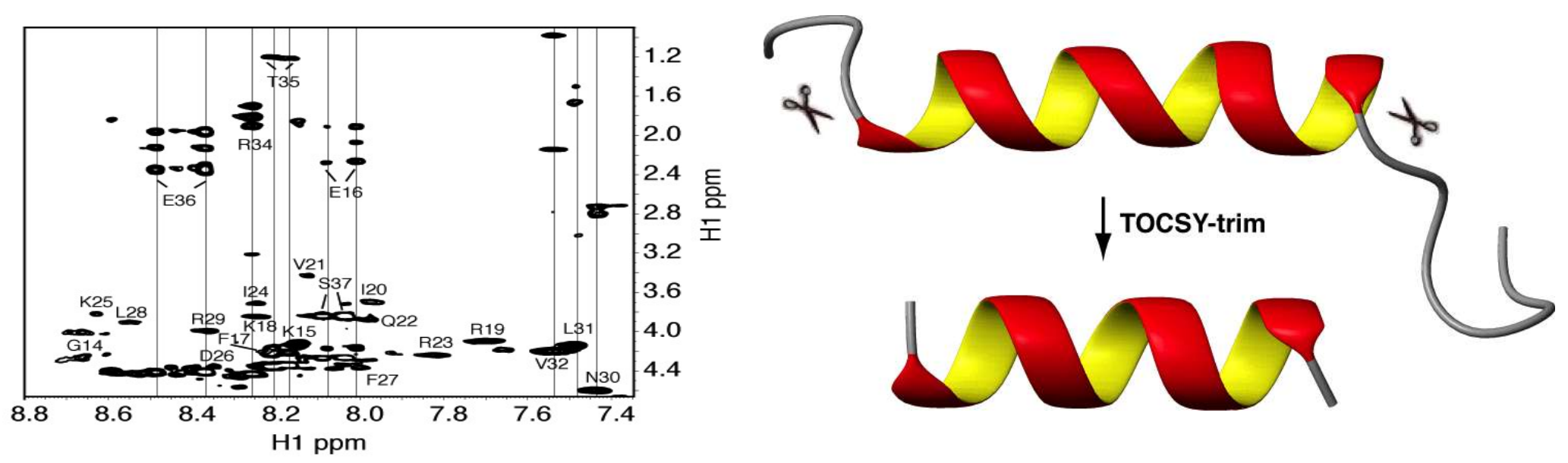

Micelle-bound state: strong peaks suggest no binding or weak binding (e.g., tails), weak peaks suggest stronger binding to micelles (e.g. the core region).

LLGDFFRKSKEKIGKEFKRIVQRIKDFLRNLVPRTES (major antimicrobial region)

The GF-17 model: G + FKRIVQRIKDFLRNLV (FK-16)

Li et al. 2006. J Am Chem Soc. May 3;128(17):5776-85. 


\section{Alanine scan of GF-17: Importance of R23 and K25}

\begin{tabular}{ll|l|l|l} 
Peptide & Sequence & $\begin{array}{l}\text { E.coli } \\
\text { K12 }\end{array}$ & $\begin{array}{l}\text { S. } \\
\text { aureus } \\
\text { UAMS-1 }\end{array}$ & $\begin{array}{l}\text { MRSA } \\
\text { USA300 }\end{array}$ \\
\hline GF-17 & GFKRIVQRIKDFLRNLV-NH 2 & 7.5 & 7.5 & 7.5 \\
K18A & GFARIVQRIKDFLRNLV-NH & 15 & 7.5 & 7.5 \\
R19A & GFKAIVQRIKDFLRNLV-NH 2 & 15 & 7.5 & 7.5 \\
R23A & GFKRIVQAIKDFLRNLV-NH & $\mathbf{6 0}$ & 7.5 & 15 \\
K25A & GFKRIVQRIADFLRNLV-NH & $\mathbf{6 0}$ & 15 & 7.5 \\
R29A & GFKRIVQRIKDFLANLV-NH & 15 & 7.5 & 7.5
\end{tabular}

Wang, G. et al. (2012). Antimicrob Agents Chemother. 56: 845-56 


\section{GF-17 can lyse bacteria much more effectively than the K25A mutant}
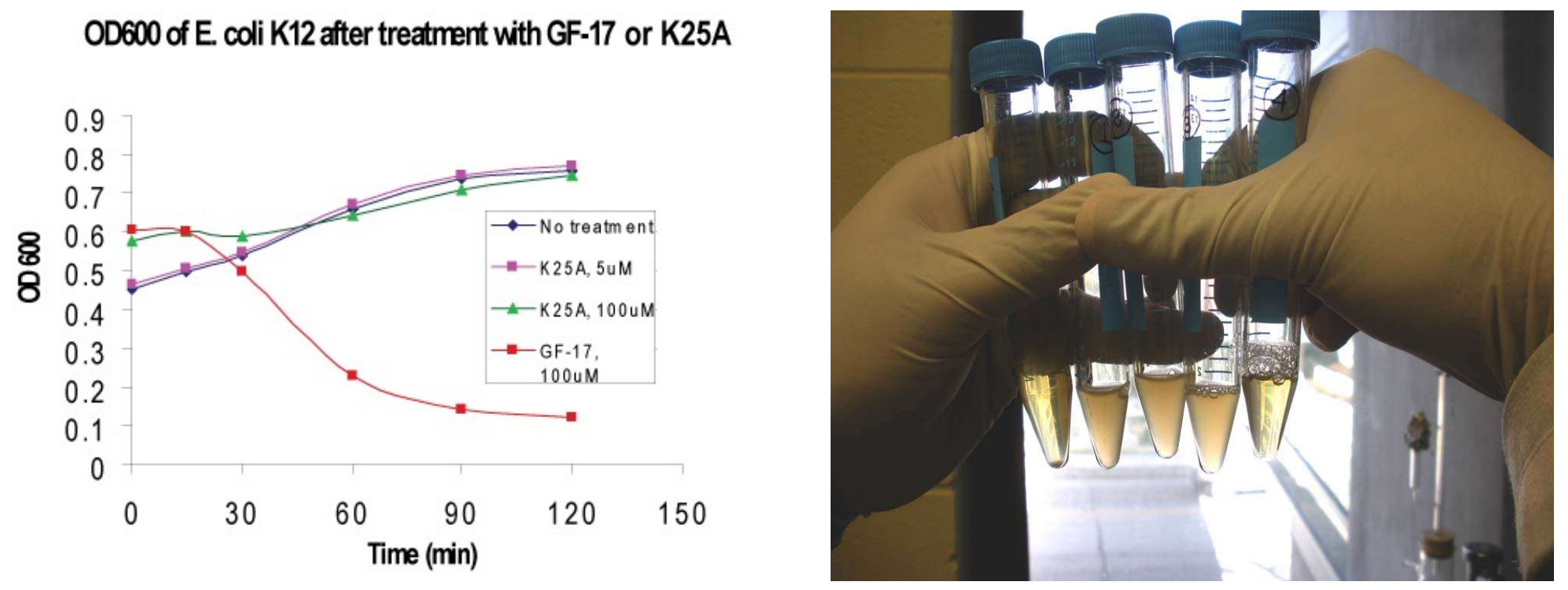

What is the physical basis of AMPs binding to bacterial membranes?

Credit: Biswajit and Tamara (Wang lab unpublished). 


\section{D8PG is a unique bacterial membrane- mimetic model for NMR studies}
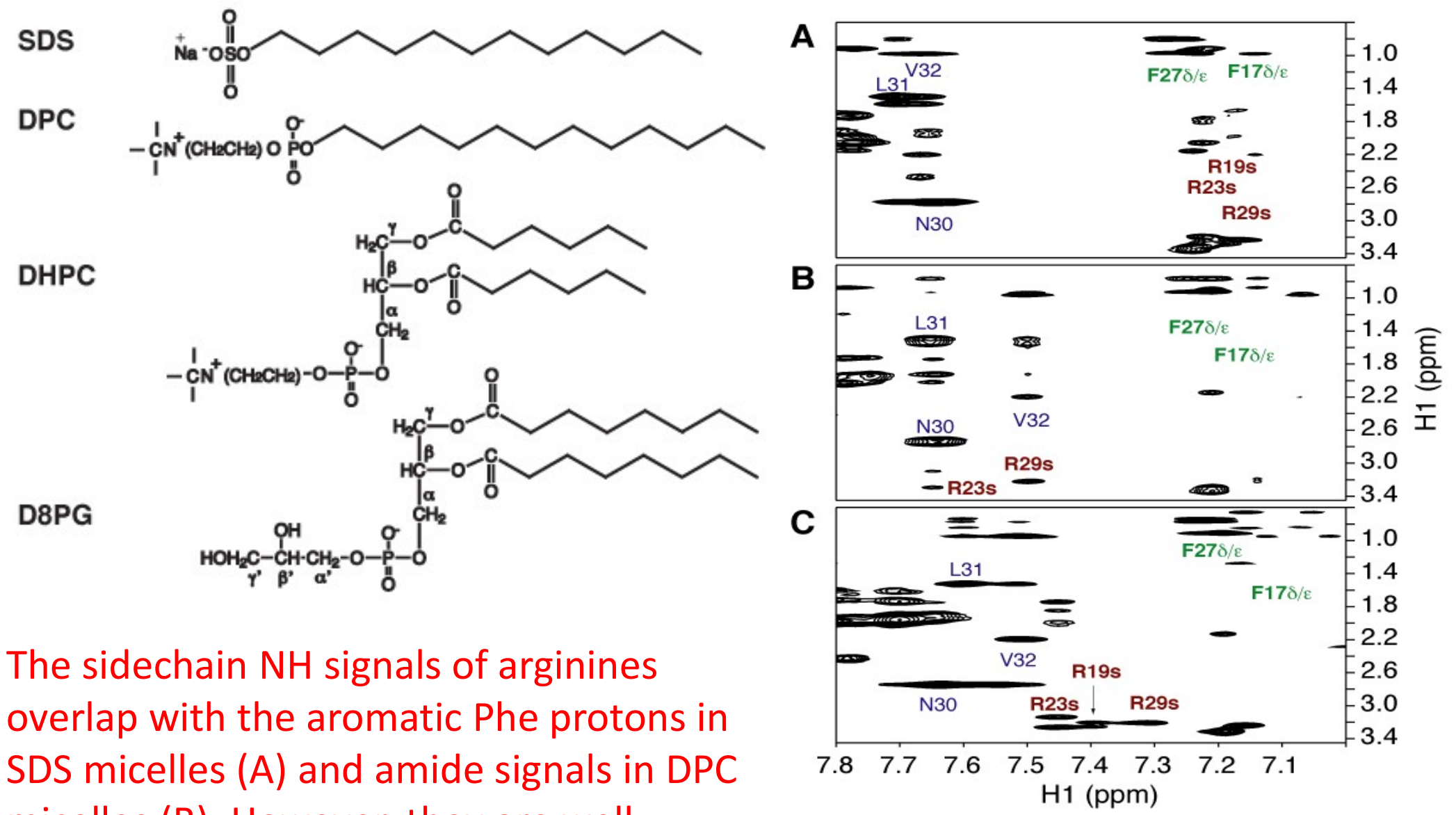

The sidechain $\mathrm{NH}$ signals of arginines overlap with the aromatic Phe protons in SDS micelles (A) and amide signals in DPC micelles (B). However, they are well resolved in D8PG (C). 


\section{Intermolecular Arg-D8PG Interactions by Solution NMR}
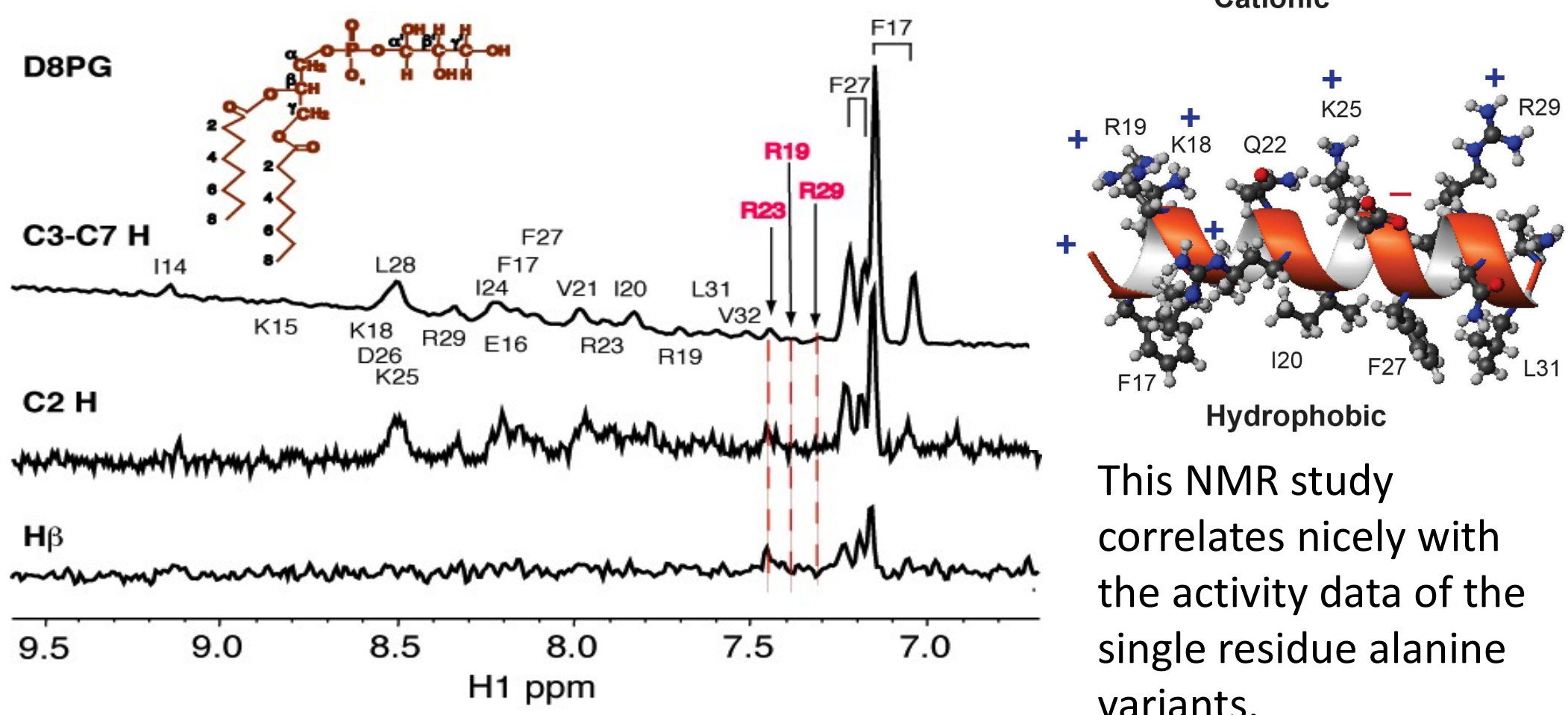

Hydrophobic

This NMR study correlates nicely with the activity data of the single residue alanine variants.

The intensity of the peptide-lipid cross peaks is inversely proportional to the distance between the peptide and lipid protons: Aromatic protons of F17 and F27 > hydrophobic backbone amides > R23 sidechain > R19/R29

Wang, G. (2007) Biochim Biophys Acta 1768: 3271-3281 
How to design selective, potent, and stable peptides? 


\section{MRSA: Simultaneous activity and stability assays in 96 -well plates}

\begin{tabular}{|l|l|l|l|}
\hline Name & Peptide amino acid sequence $^{\mathrm{a}}$ & $\begin{array}{l}\text { MIC } \\
(\mu \mathrm{M})\end{array}$ & Stability $^{\mathrm{b}}$ \\
\hline FK-21 & FKRIVQRIKDFLRNLVPRTE & 160 & - \\
\hline GK-21 & GKEFKRIVQRIKDFLRNLVPR & 40 & - \\
\hline KI-22 & KIGKEFKRIVQRIKDFLRNLVP & 10 & - \\
\hline EK-20 & EKIGKEFKRIVQRIKDFLRN & $>160$ & - \\
\hline KR-12 & KRIVQRIKDFLR & $>160$ & - \\
\hline GF-17 & GFKRIVQRIKDFLRNLV & 2.5 & - \\
\hline GF-16 & GFKRIVQRIKDFLRNL & 10 & - \\
\hline BMAP- & GRFKRFRKKFKKLFKKLS & $>160$ & - \\
18 & & & \\
\hline GF-17d3 & GFKRIVQRIKDFLRNLV & $>160$ & $+^{c}$ \\
\hline
\end{tabular}

GF-17d3 retained activity against $\mathrm{E}$. coli in the presence of chymotrypsin, but lost activity against MRSA.

Wang G et al. (2014). ACS Chem Biol 9: 1997-2002 


\section{Structures of GF-17 (helical) and GF-17d3 (non-helical)}

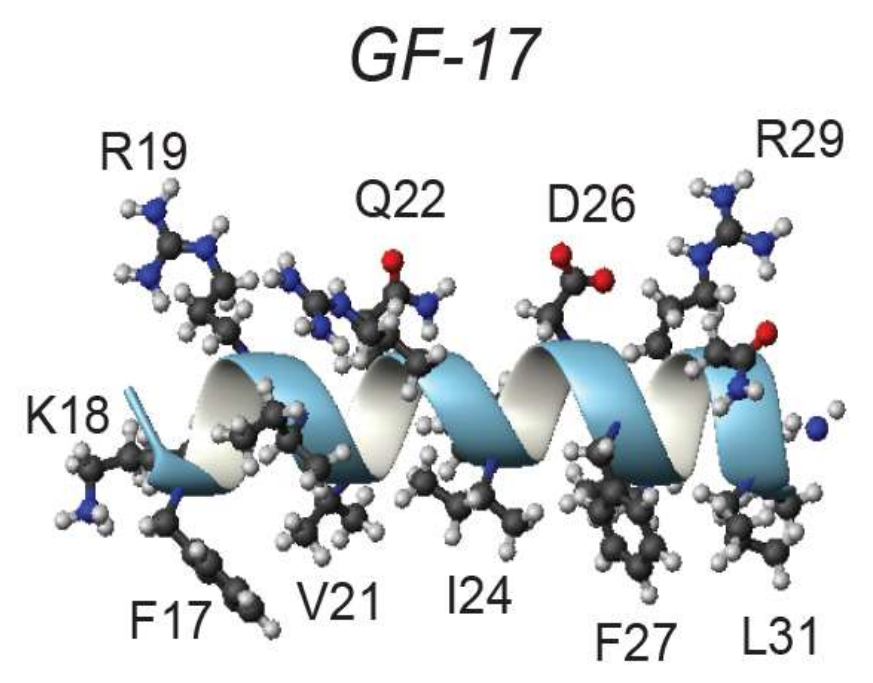

Protease-

susceptible

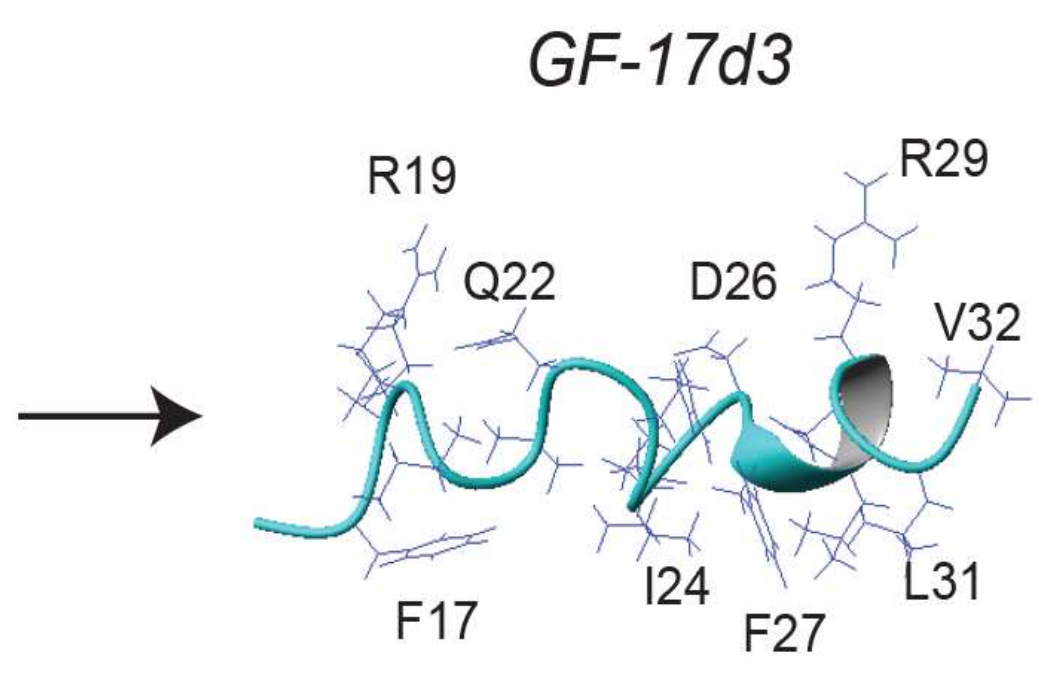

Chymotrypsinresistant 


\section{Structure-based design of antimicrobial agents}
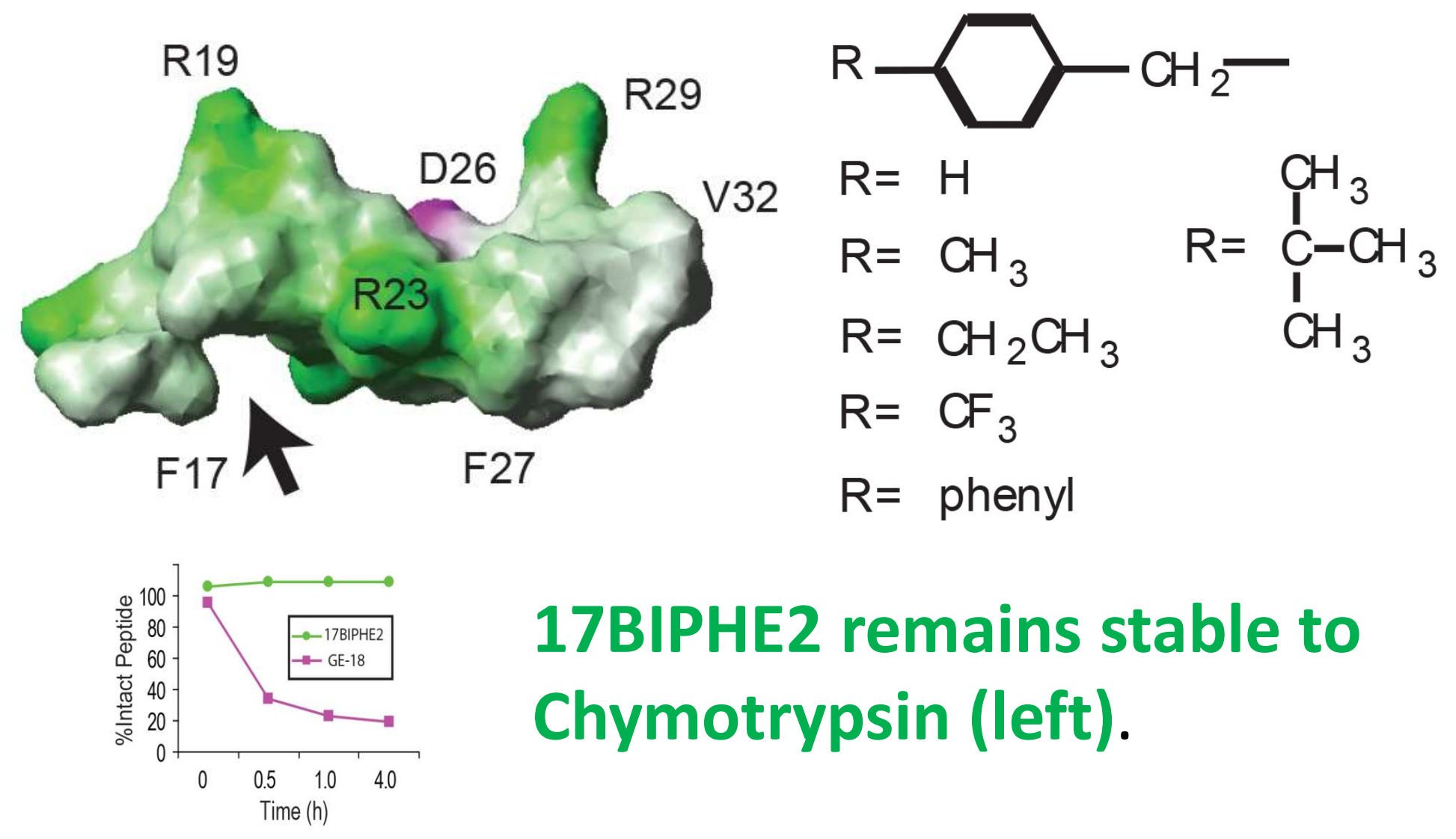

Wang G et al. (2014) ACS Chem. Biol. 9: 1997-2002. 


\section{The ESKAPE Pathogens}

Enterococcus faecium (VRE);

Staphylococcus aureus (MRSA);

Klebsiella pneumonia (nightmare);

Acinetobacter baumannii;

Pseudomonas aeruginosa;

Enterobacter species. 


\section{BIPHE2 is effective against the ESKAPE pathogens}

\begin{tabular}{|c|c|c|c|c|c|c|c|}
\hline \multirow[t]{2}{*}{ Peptide } & \multicolumn{6}{|c|}{$\mathrm{MIC}(\mu \mathrm{M})$} & \multirow{2}{*}{$\begin{array}{c}\mathrm{HL}_{50} \\
(\mu \mathrm{M})^{\mathrm{b}}\end{array}$} \\
\hline & E. faecium & S. aureus & $\begin{array}{c}K . \\
\text { pneumonia }\end{array}$ & A. baumannii & $\begin{array}{c}P . \\
\text { aeruginosa }\end{array}$ & E. cloacae & \\
\hline $17 F 2$ & $>100$ & $>100$ & $>100$ & $6.2-12.5$ & 100 & 25 & $>900$ \\
\hline $17 \mathrm{mF}-\mathrm{F}$ & $25-50$ & 25 & 50 & $3.1-6.2$ & 25 & 25 & $>900$ \\
\hline 17F-Naph & 3.1 & 25 & 25 & 3.1 & 12.5 & 12.5 & $>900$ \\
\hline 17mF-Naph & 3.1 & 6.2 & 12.5 & 3.1 & $6.2-12.5$ & 6.2 & 500 \\
\hline 17Naph-mF & 3.1 & 6.2 & 12.5 & 3.1 & $6.2-12.5$ & $6.2-12.5$ & 950 \\
\hline 17BIPHE & 12.5 & 12.5 & 25 & 3.1 & 12.5 & 12.5 & $>900$ \\
\hline 17BIPHE2 & 3.1 & 3.1 & 3.1 & 3.1 & 6.2 & 3.1 & 225 \\
\hline
\end{tabular}

Wang G et al. (2014). ACS Chem Biol 9: 1997-2002. 


\section{BIPHE2 damages bacterial Membrane}
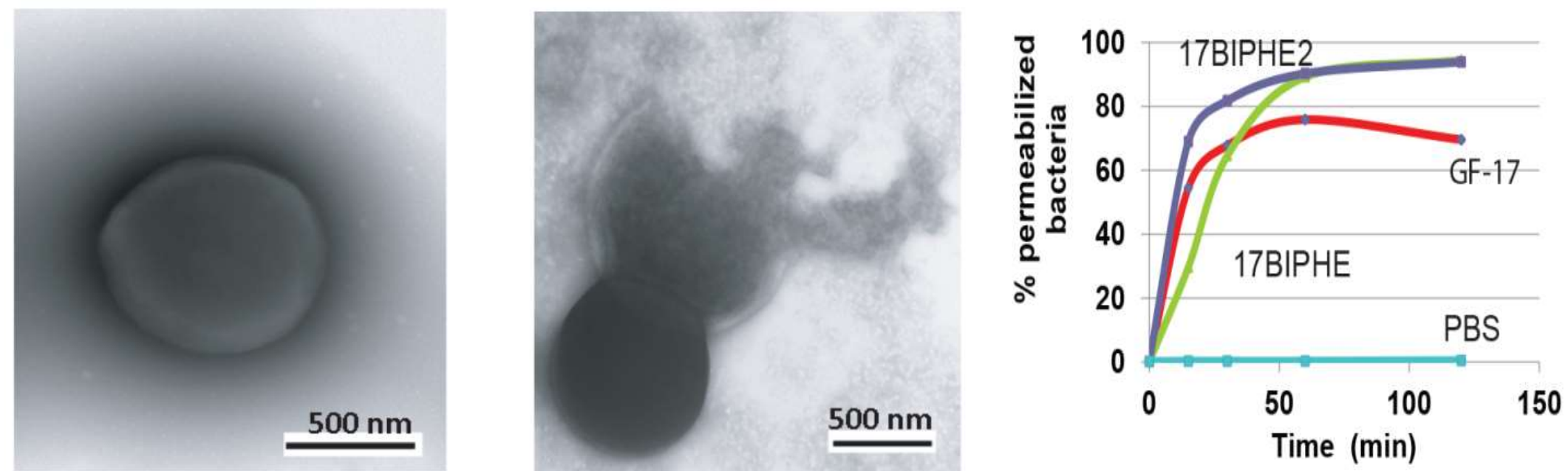

TEM: before and after peptide treatment.

Propidium iodide: membrane permeation is slightly more potent than GF-17 


\section{In vivo model l: the wax moths model illustrate advantages of peptide engineering}
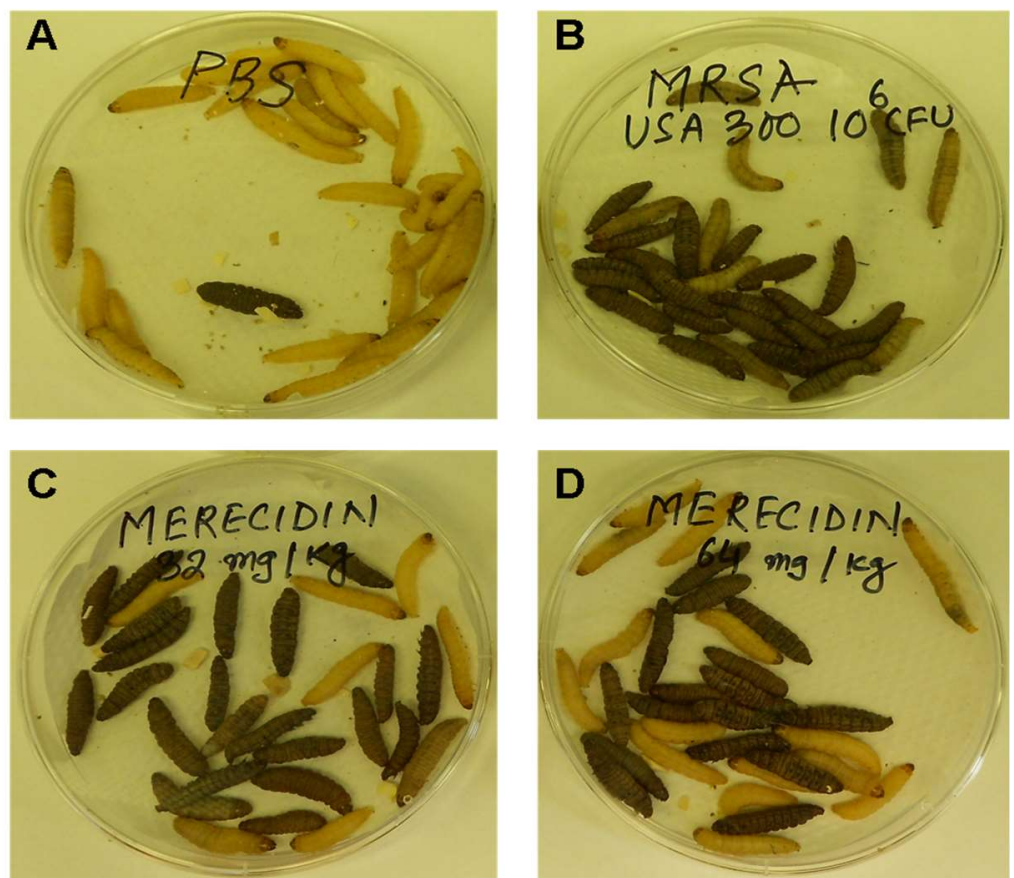

Galleria mellonella

LL-37
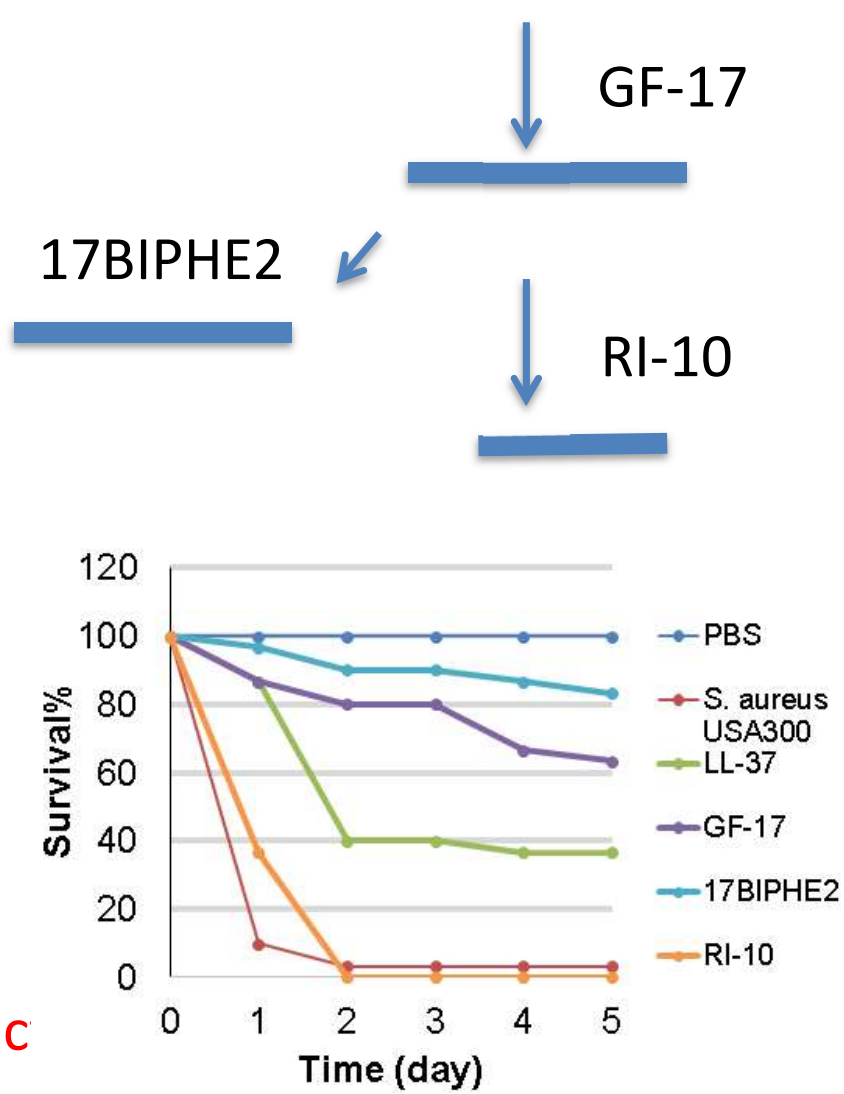

in this model compared to LL-37 and its native fragments. 


\section{In vivo model II: a catheter S. aureus Biofilm model (by Tammy Kielian's lab)}

A

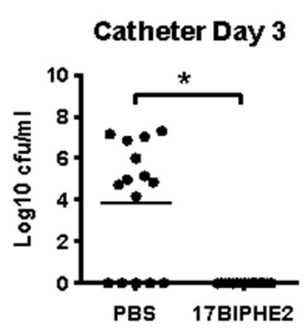

D

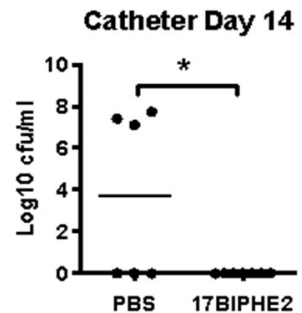

G

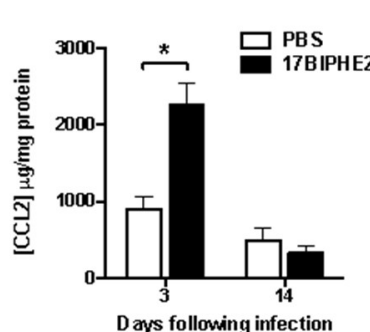

B

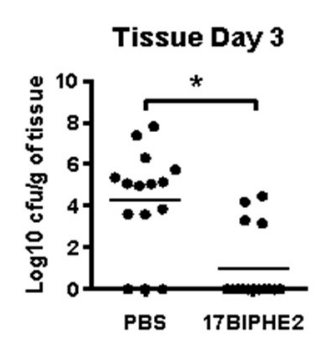

E
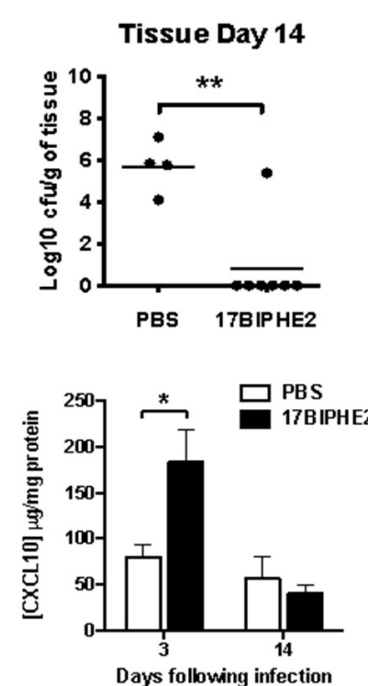

C
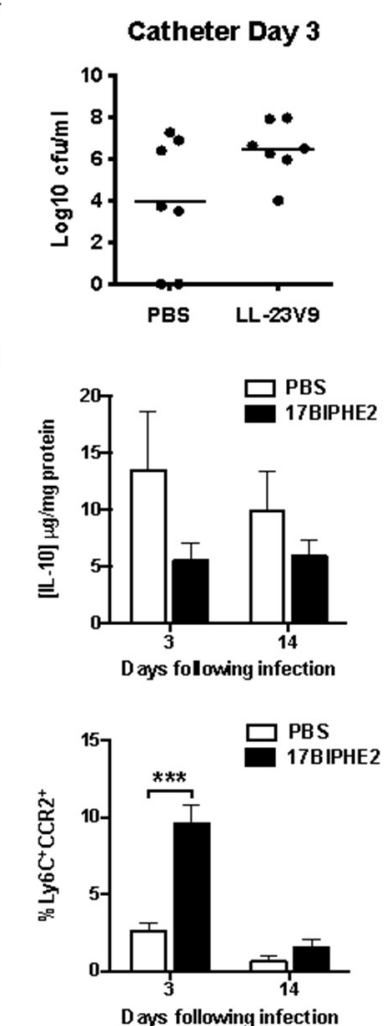

While an inactive peptide did not work (c), 17BIPHE2 was effective in reducing MRSA CFU in the catheters (A \& D) and surrounding tissues ( $B$ \& E) at both days 3 and 14 . In addition, the peptide was able to induce MCP-1 at day 3 (G) that recruited monocytes (I) to further clear the infection.

Wang G et al. (2014) ACS Chem. Biol. 9: 1997-2002 42 
The NMR structure of LL-37

bound to SDS micelles

A. Superimposed Backbone;

B. Ribbon diagram;

C. Potential surface.
A

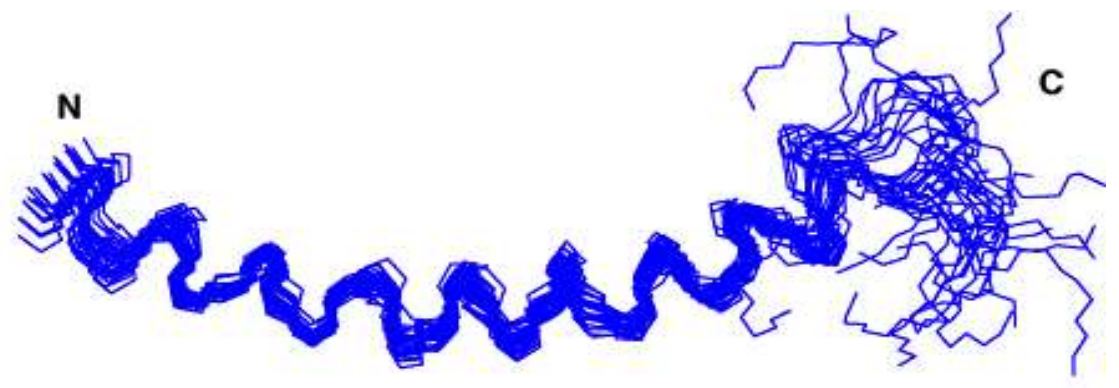

B

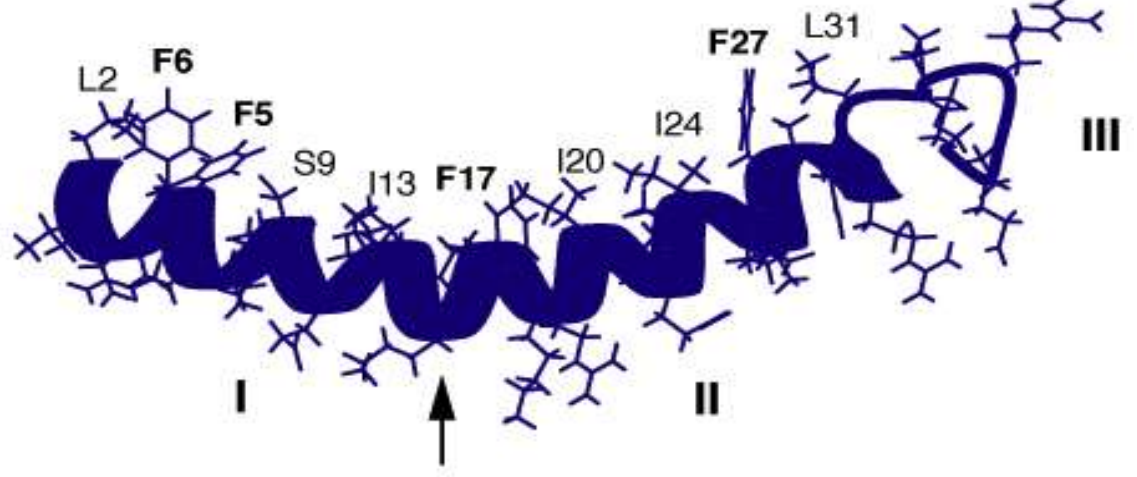

C

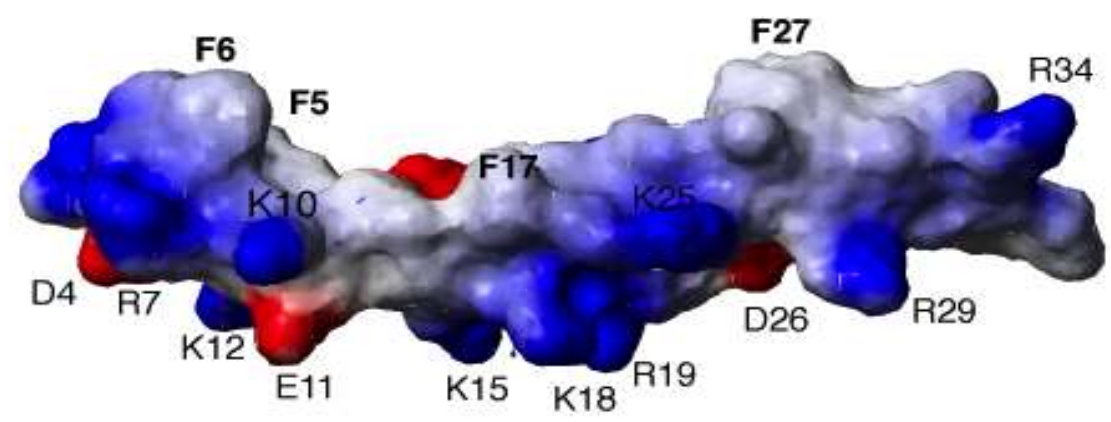

3D NMR studies revealed a helical structure for human LL-37 covering residues 2-31, while the tail portion is disordered.

Wang, G. (2008) J Biol Chem 283: 32637. 


\section{NMR Dynamics: Depicting the Motional Picture of Micelle-bound Human LL-37}

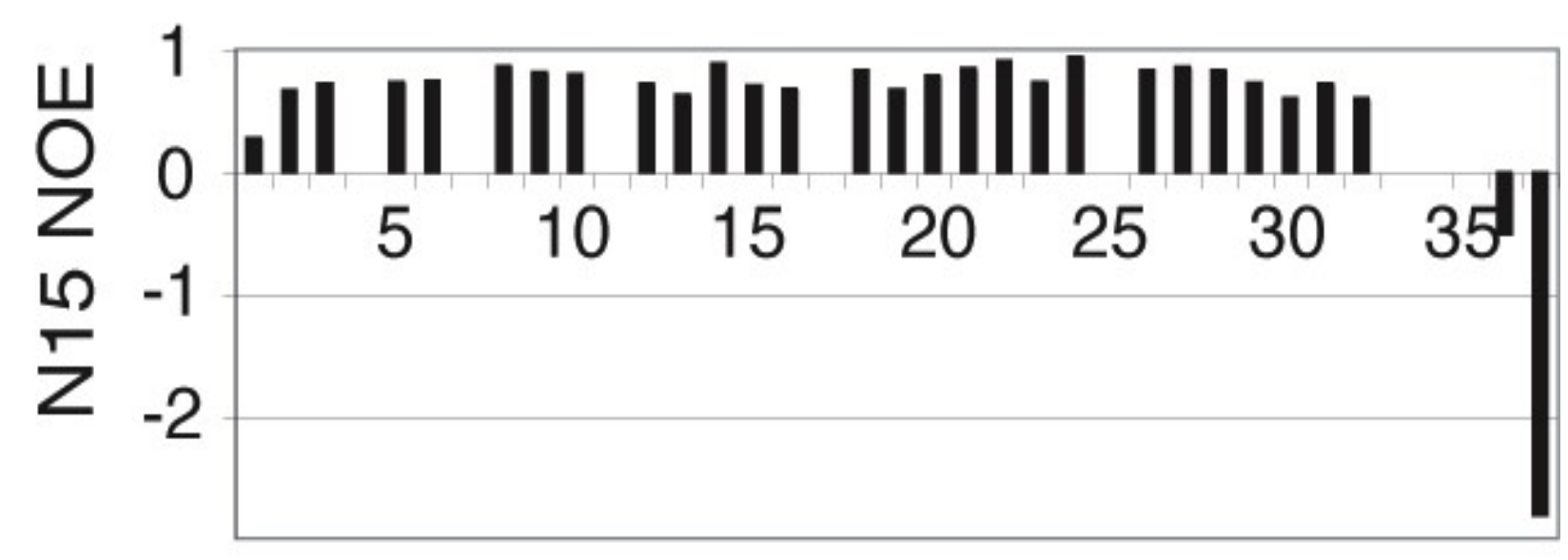

\section{Residue Number}

This figure indicates that residues 2-32 are ordered, while the Cterminal tail of LL-37 is mobile. This picture is fully consistent with the 3D structure of LL-37 determined independently without using this backbone dynamics information.

Wang, G. (2008) J Biol Chem 283: 32637. 


\section{Structural light on antibacterial, antibiofilm, and antiviral activity of LL-37}

A

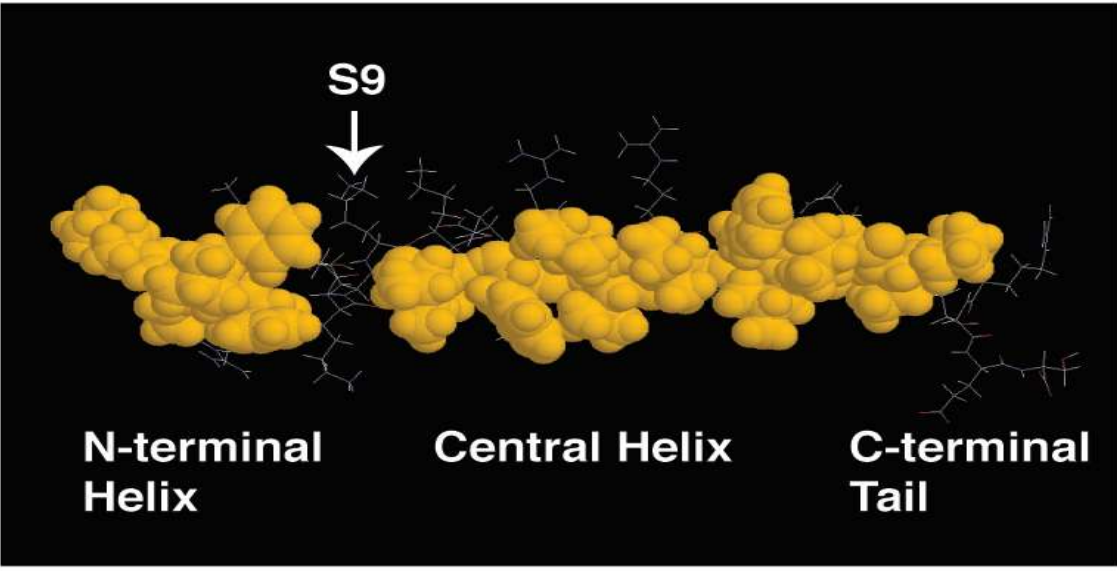

B

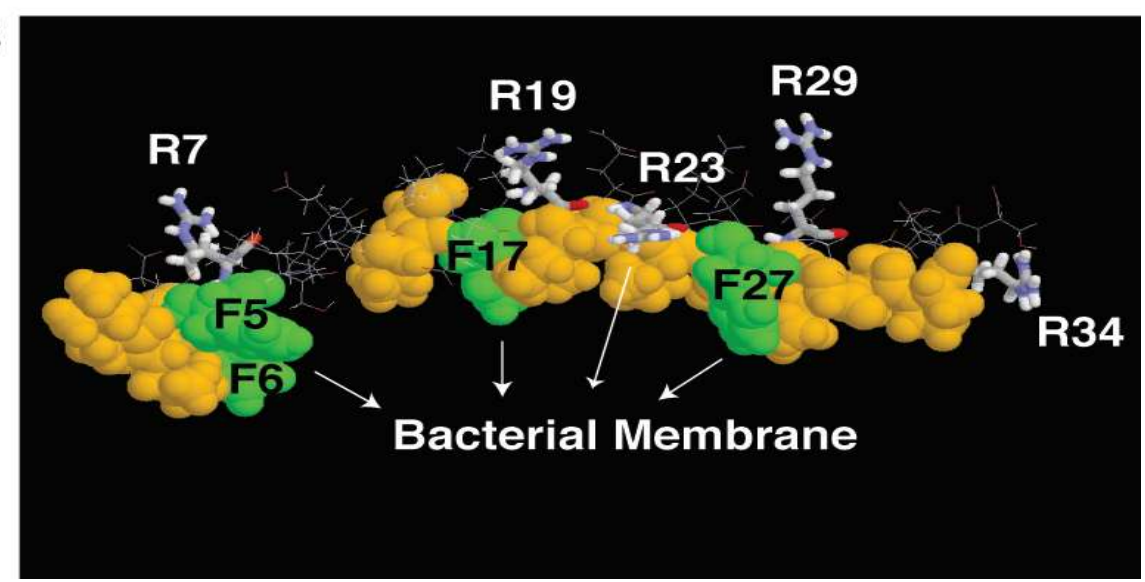

Wang et al. (2014) Biochim. Biophys. Acta 1838: 2160-2172.

\section{Structural validation}

1: Peptide dynamics.

Validation 2: structure bound to anionic phosphatidylglycerol is the same.

Validation 3: structure bound to LPS also indicates a disordered C-terminal tail. 


\section{Sequence-dependent activity: Templates for peptide engineering}

\begin{tabular}{ll|l|l} 
Peptide & Amino acid sequence & LL-37 region & Activity \\
\hline KR-12 & KRIVQRIKDFLR & $18-29$ & E. coli \\
\hline FK-13 & FKRIVQRIKDFLR & $17-29$ & HIV \\
\hline GF-17 & FKRIVQRIKDFLRNLV & $17-32$ & MRSA/biofilms/cancer \\
\hline GI-20 & GIKEFKRIVQRIKDFLRNLV & $13-32$ & Viruses/immune \\
\hline RK-25 & RKSKEKIGKEFKRIVQRIKDFLRNL & $7-31$ & Biofilm \\
& & &
\end{tabular}

Wang G et al. (2014). Biochim Biophys Acta. Sep;1838(9):2160-72. 


\section{Light therapy for TB, Vitamin D and LL-37}

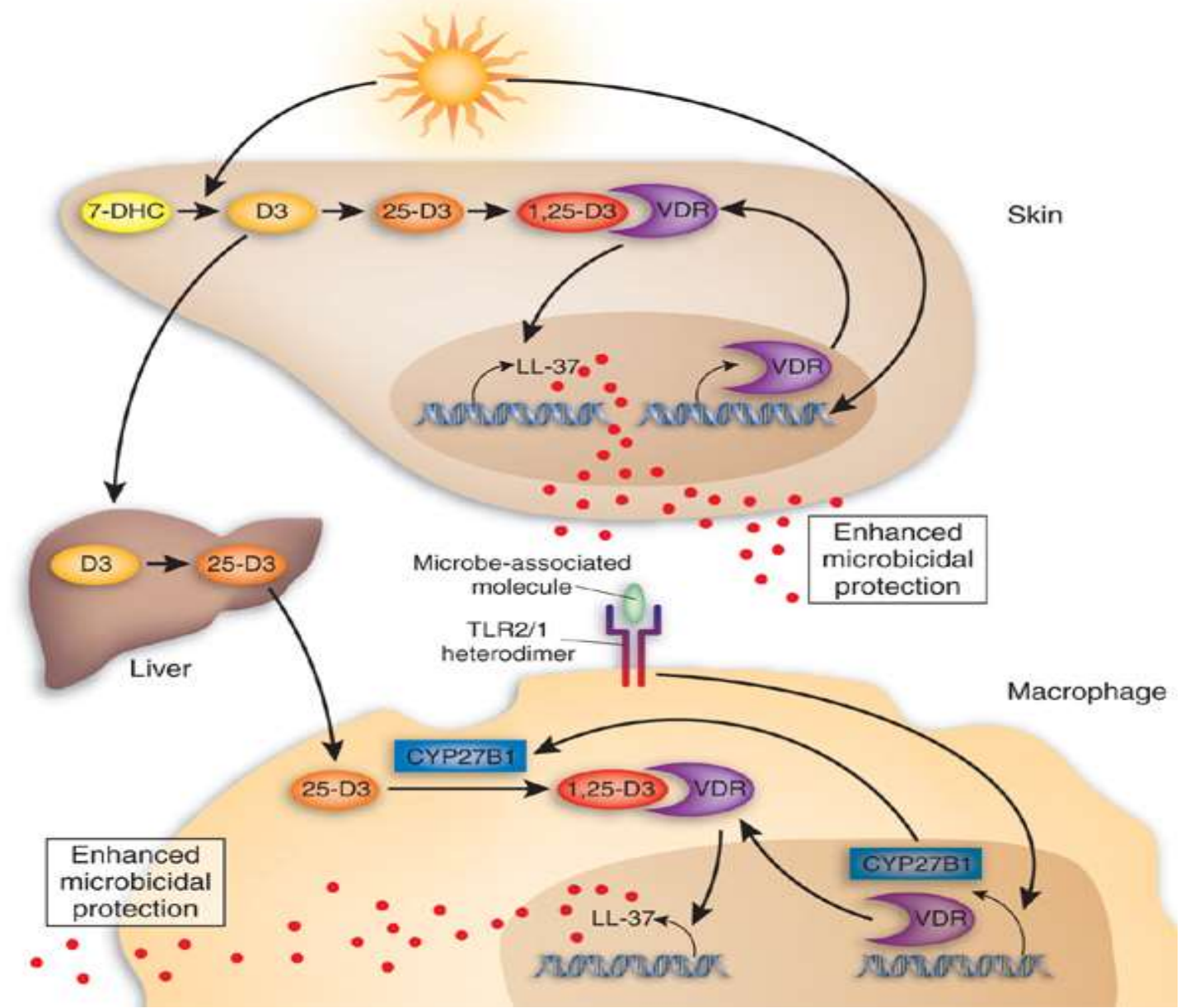

Liu $P$ et al. (2006) Tolllike receptor triggering of a vitamin Dmediated human antimicrobial response.

Science 311: 1770-3. 


\section{Advanced application strategies}

a. Prodrug Protease

Targeting Linker

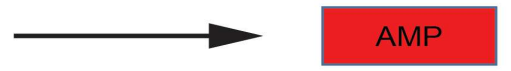

b. Conjugation

Enhancer AMP

\section{c. Combined use}

Antimicrobials
(e.g. antibiotic)
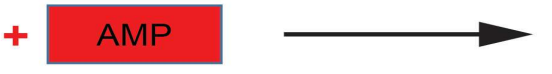

Synergistic/additive effects

d. AMP induction

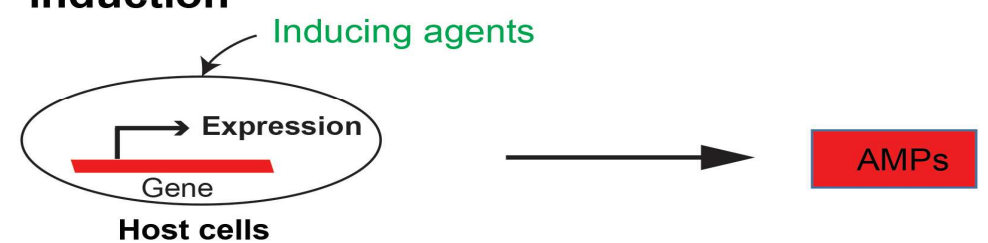

e. Probiotic bacteria

$$
\begin{aligned}
& \underset{P}{\longrightarrow \text { Expression }} \\
& \text { Lactic acid bacteria }
\end{aligned}
$$

AMP production

Mishra, B., Reiling, S., Zarena, D., Wang, G. 2017. Host defense antimicrobial peptide as antibiotics: design and application strategies. Curr. Opin. Chem. Biol. 38, 87-96. 


\section{Summary}

1. Over 3000 natural antimicrobial peptides have been identified and registered in the antimicrobial peptide database (http://aps.unmc.edu/AP). Importantly, some AMPs are already in use.

2. There is a great interest in developing the therapeutic use of human cathelicidin LL-37.

3. Both library screen and structure-based design are in use. They can be combined.

4. LL-37 derived peptides can kill the ESKAPE pathogens, disrupt biofilms, and show topical efficacy in animal models.

5. The engineered peptide 17BIPHE2 is superior to LL-37 and its native fragments in protecting the wax moths. 


\section{Acknowledgements}

Lab members:

Zhe Wang

Xia Li

Biswajit Mishra

Tamara Lushnikova

Radha Golla

Xiuqing Wang

Kyle Lau

Kaiyan Jin

Dudekula Zarena

Fangyu Wang

Jayaram L. Narayana

Yingxia Zhang

Qianhui Wu
Collaborators:

Robert Buckheit (ImQuest)

Richard Epand (McMaster)

Tammy Kielian (UNMC)

Kenneth Bayles (UNMC)

Bob Hancock (UBC)

Richard Gallo (UCSD)

G. Bachrach (The Hebrew University-Hadassah)

Keven Hartshorn (Boston U)

Nuch Tanphaichitr (Ottawa U) Jialin Zheng (UNMC)

The research of the Wang lab is supported by the NIAID/NIH Al145107 and Al128230). 


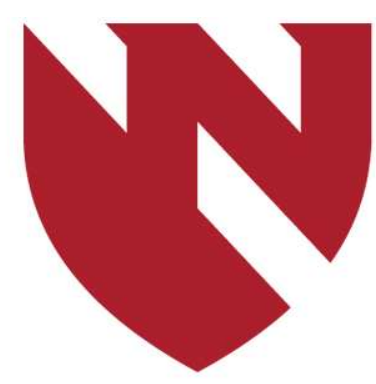

\section{UNMC}

BREAKTHROUGHS FOR LIFE:

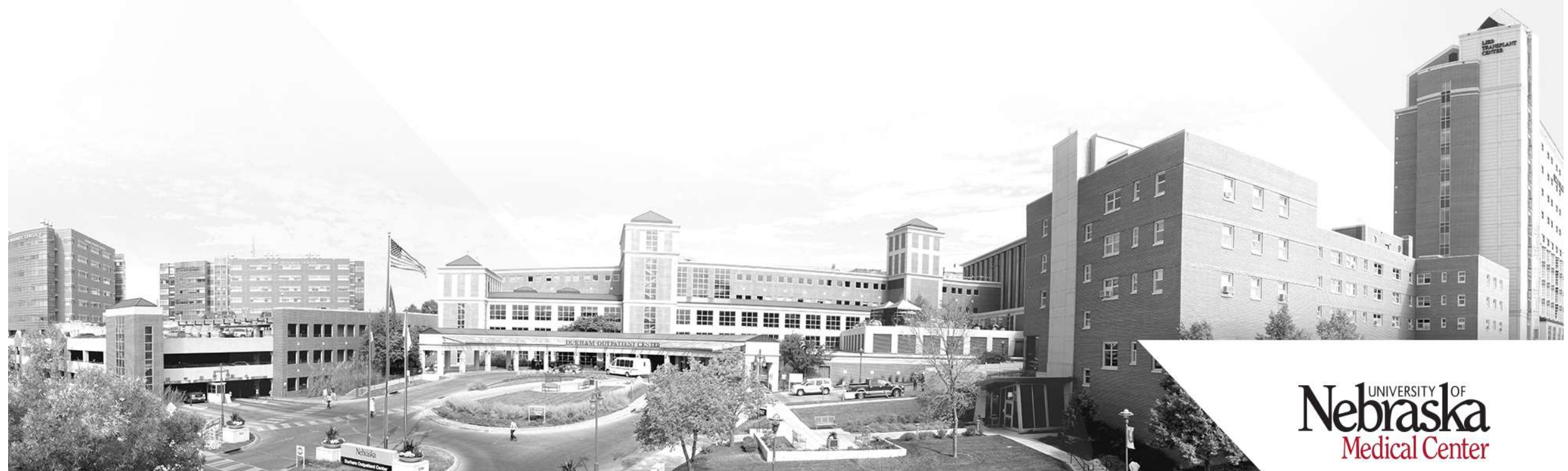

